\title{
Hypothermia Regulates Insulin-like Growth Factor 1 Gene Expression in PC12 Cells
}

\author{
Bo-Kyung Yoo ${ }^{1,}$, Kisang Kwon ${ }^{2, \$}$, Eun Ryeong Lee ${ }^{2}$, Seung-Whan Kim ${ }^{3}$, \\ Kweon $\mathrm{Yu}^{4}$ and O-Yu Kwon ${ }^{1, \dagger}$ \\ ${ }^{I}$ Department of Anatomy \& Cell Biology, College of Medicine, Chungnam National University, \\ Daejeon 35015, Korea \\ ${ }^{2}$ Department of Biomedical Laboratory Science, College of Health \& Welfare, Kyungwoon University, \\ Gumi 39160, Korea \\ ${ }^{3}$ Department of Emergency Medicine, Chungnam National University Hospital, Daejeon 35015, Korea \\ ${ }^{4}$ Korea Research Institute of Bioscience \& Biotechnology, Daejeon 34141, Korea
}

In this study, we evaluated the effects of various hypothermic conditions $\left(32^{\circ} \mathrm{C}\right)$, including lithium chloride treatment, on insulin-like growth factor 1 (IGF-1) gene expression in PC12 cells. The results show that short-term hypothermic treatment ( $<1$ day) resulted in relatively higher IGF-1 gene expression than did longer-term treatment $(>1$ day). Repeated switching between normal temperature and hypothermia every $2 \mathrm{~h}$ increased IGF-1 gene expression approximately 3-4-fold. These findings indicate that hypothermia dynamically regulates IGF-1 gene expression. This study could be helpful for the development of treatment and diagnostic strategies for ischemia.

Key Words: Hypothermia, Insulin-like growth factor 1 (IGF-1), PC12 cells

Currently, clinical treatments that reduce the after-effects of acute ischemic stroke are not well established. Tissue plasminogen activator (t-PA) injection therapy within $3 \mathrm{~h}$ post-acute ischemic stroke is one of the most effective methods. However, t-PA is associated with serious issues, such as time limitations and risk of bleeding (Wardlaw et al., 2012). Anti-platelet agents have recently received much attention for their therapeutic effects. However, these effects remain unclear. Hypothermia treatment is defined as a core body temperature below $35^{\circ} \mathrm{C}\left(32^{\circ} \mathrm{C}\right)$ to achieve protection and/or good clinical outcomes. Its advantages were shown for the medical management of refractory intracranial hyper- tension and malignant cerebral edema (Imataka and Arisaka, 2015). American Heart Association guidelines on therapeutic hypothermia (2005) state that unconscious adult patients with return of spontaneous circulation after out-of-hospital cardiac arrest should be cooled to $32 \sim 34^{\circ} \mathrm{C}$ for $12 \sim 24 \mathrm{~h}$, and similar therapy may be beneficial for patients with non-ventricular fibrillation (VF) arrest out of hospital or in hospital (American Heart Association, 2006). Although hypothermia treatment has many benefits for neurocritical care and patient rehabilitation, the mechanisms involved in the regulation of cellular function are obscure. The molecular mechanisms proposed include apoptosis and mitochondrial

* Received: October 14, 2016 / Revised: February 8, 2017 / Accepted: February 9, 2017

${ }^{\S}$ Authors contributed equally to this work.

${ }^{\dagger}$ Corresponding author: O-Yu Kwon. Department of Anatomy \& Cell Biology, College of Medicine, Chungnam National University, Daejeon 35015, Korea. Tel: +82-42-580-8206, Fax: +82-42-586-4800, e-mail: oykwon@cnu.ac.kr

(C) The Korean Society for Biomedical Laboratory Sciences. All rights reserved.

(c) This is an Open Access article distributed under the terms of the Creative Commons Attribution Non-Commercial License (http://creativecommons.org/licenses/by-nc/3.0/) which permits unrestricted non-commercial use, distribution, and reproduction in any medium, provided the original work is properly cited. 
dysfunction, inflammation, blood-brain barrier disruption, free radical production, and rescue of the RNA-binding motif protein 3 gene (Al-Astal et al., 2016; Yenari and Han, 2012; Yenari and Zhao, 2003).

In this study, we used the differential display-polymerase chain reaction (PCR) method to determine the differentially expressed genes regulated by hypothermia treatment in PC12 culture cells (Sturtevant, 2000). The results show that a gene encoding insulin-like growth factor 1 (IGF-1) was differentially up-regulated by hypothermic conditions. IGF-1 was first identified in 1957 by Salmon and Daughaday as a 'sulphation factor' (Salmon and Daughaday, 1957). In 1972, the gene name was changed to 'somatomedin' (Daughaday et al., 1972); in 1976, it was renamed 'IGF-1' because of its structural resemblance to proinsulin (Rinderknecht and Humbel, 1976). IGF-1, similar to insulin, is a small peptide consisting of 70 amino acids in a single chain with three intramolecular disulfide bridges and a molecular weight of 7,649 daltons (Rinderknecht and Humbel, 1978). The human IGF-1 gene, located on the long arm of chromosome 12q2323, consists of six exons and two promoters (Mullis et al., 1991; Rotwein, 1991). IGF-1 is primarily secreted from the liver and binds to one of six IGF binding proteins for transport to other tissues, where it functions as an endocrine hormone. The main function of IGF-1 is to mediate growth hormone-stimulated somatic growth. Other important functions include osteogenesis, axonal generation in nerves, nerve regeneration after ischemic insult, muscle repair, and hypertrophy after trauma or exercise (Cheng et al., 2007).

For reverse transcription-PCR (RT-PCR) analysis, PC12 cells were cultured on collagen-coated flasks in 85\% RPMI 1640 supplemented with $25 \mathrm{mM}$ HEPES buffer, $10 \%$ heatinactivated horse serum, $5 \%$ heat-inactivated fetal bovine serum, $2 \mathrm{mM}$ L-glutamine, $1 \mathrm{mM}$ sodium pyruvate, $1 \mathrm{~g} / 1$ d-(+)-glucose, $25 \mu \mathrm{g} / \mathrm{ml}$ streptomycin, and $25 \mathrm{U} / \mathrm{ml}$ penicillin at $37^{\circ} \mathrm{C}$ in a $5 \% \mathrm{CO}_{2}$ atmosphere. Cells were incubated under control conditions $\left(37^{\circ} \mathrm{C}\right)$ or hypothermia $\left(32^{\circ} \mathrm{C}\right)$. The expression of cold-induced RNA-binding protein (CIRBP) was used as a positive control (Al-Fageeh and Smales, 2009) in all experiments. Total RNA was extracted from cultured PC12 cells using NucleoZOL (MachereyNagel, Duren, Germany). RT-PCR was performed using Taq DNA polymerase and the primers 5'-GCTCCATCCACCTTACAGGA-3' (forward) and 5'-GGCACTGGGAAATACCTTGA-3' (reverse) for IGF-1 and 5'-TCAGCTTCGACACCAATGAG-3' (forward) and 5'-GTATCCTCGGGACCGGTTAT-3' (reverse) for CIRBP. The conditions for 30 cycles were $94^{\circ} \mathrm{C}$ for $30 \mathrm{~s}, 58^{\circ} \mathrm{C}$ for $30 \mathrm{~s}$, and $72^{\circ} \mathrm{C}$ for 1 min, with a final $72^{\circ} \mathrm{C}$ for 10 min incubation.

Compared with the control, IGF-1 gene expression showed
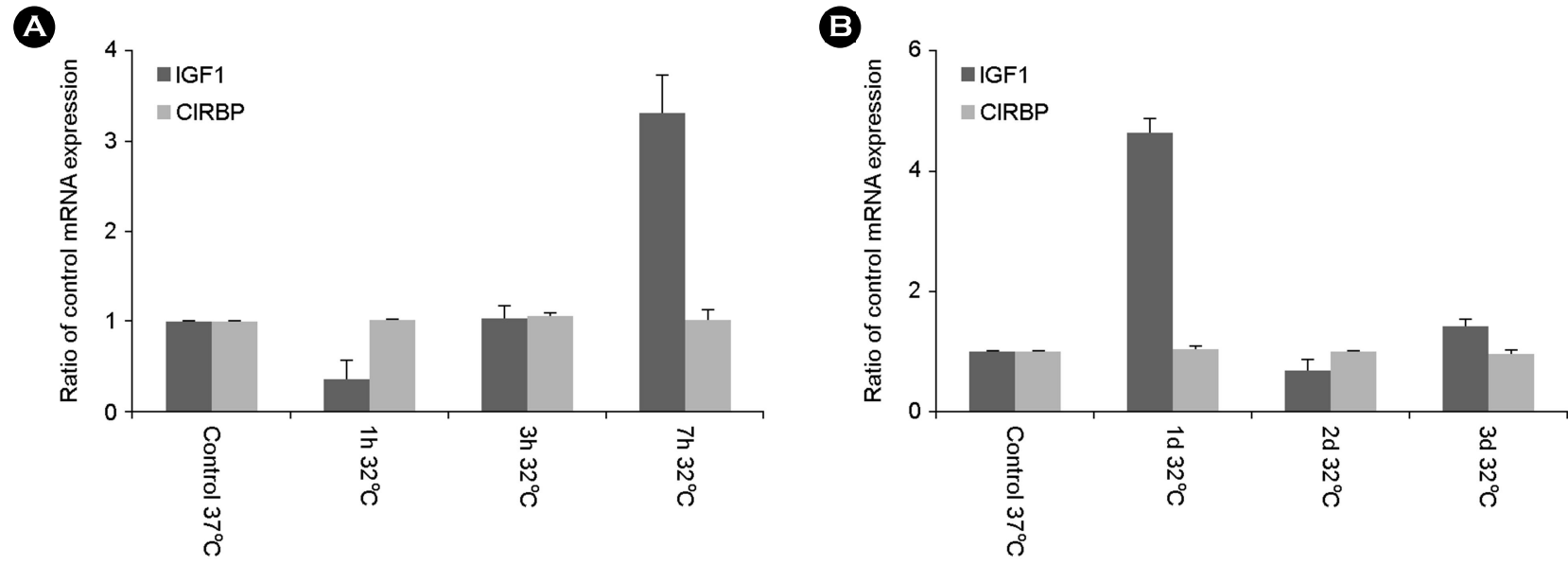

Fig. 1. Hypothermia regulates IGF-1 gene expression. PC12 cells were exposed to hypothermia $\left(32^{\circ} \mathrm{C}\right)$ for different durations. The hypothermic response was confirmed by an increase in CIRBP mRNA expression, which is a positive marker. IGF-1, insulin-like growth factor 1; CIRBP, cold-induced RNA-binding protein. The experiments were performed thrice, and the results represent the means. In the text, Fig. $1 \mathrm{~A}$ and $1 \mathrm{~B}$ are referenced. 
no change after $3 \mathrm{~h}$ of exposure to hypothermia $\left(32^{\circ} \mathrm{C}\right)$; however, after $7 \mathrm{~h}$, IGF-1 gene expression increased approximately 3.5-fold (Fig. 1A). IGF-1 gene expression (approximately 5 -fold) reached its maximum on day 1 of hypothermia treatment, after which it decreased rapidly and then maintained a level similar to that of the control on days $1 \sim 3$

(Fig. 1B). These results suggest that hypothermia increases
IGF-1 gene expression only in the short-term ( $<1$ day) in PC12 cell cultures. Moreover, an additional $1 \mathrm{~h}$ exposure to $37^{\circ} \mathrm{C}$ after 1 day of $32^{\circ} \mathrm{C}$ treatment caused a 2-fold increase in IGF-1 expression, whereas an additional $3 \mathrm{~h}$ exposure to $37^{\circ} \mathrm{C}$ after 1 day of $32^{\circ} \mathrm{C}$ treatment caused a 7-fold increase in gene expression (Fig. 2A). Additionally, 1 and $3 \mathrm{~h}$ exposures to normal temperature after 2 days of hypothermic
A

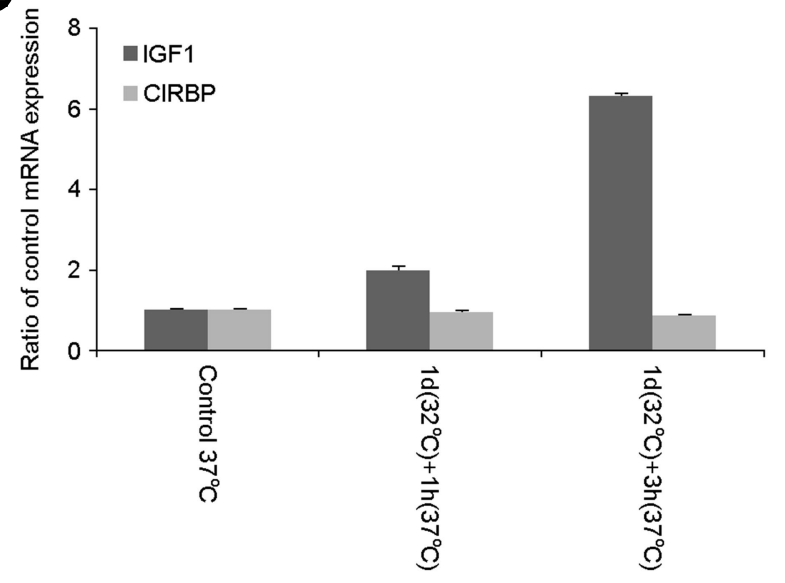

B

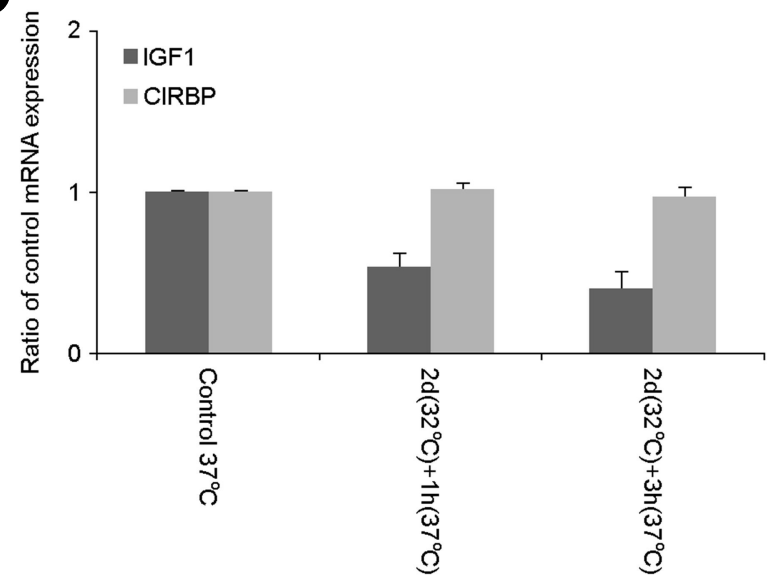

Fig. 2. Intermittent hypothermia induces differential IGF-1 gene expression. PC12 cells were exposed to intermittent hypothermia $\left(32^{\circ} \mathrm{C}\right)$ and continuous control conditions $\left(37^{\circ} \mathrm{C}\right)$ for different durations (A) and (B). IGF-1, insulin-like growth factor 1; CIRBP, coldinduced RNA-binding protein. The experiments were performed thrice, and the results represent the means.

A

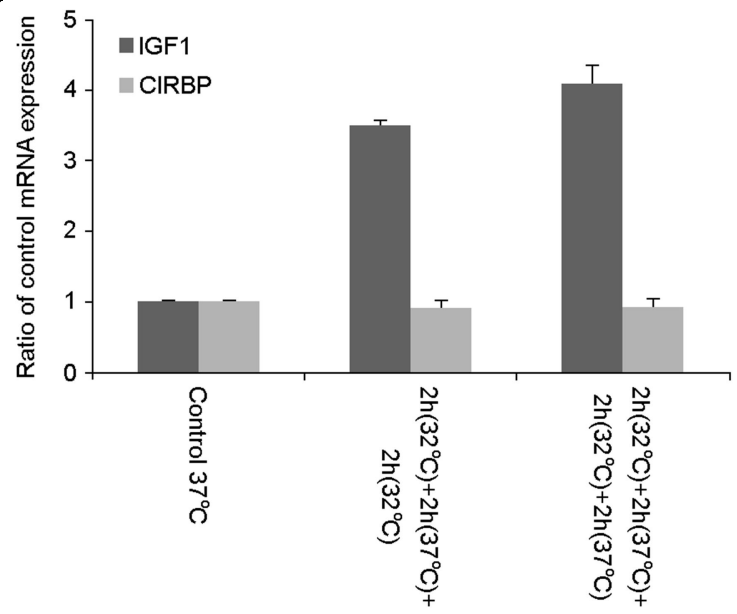

B

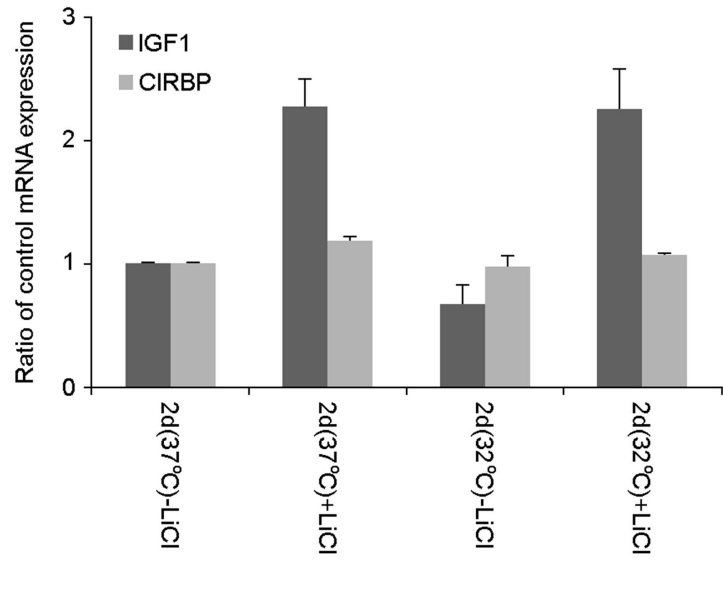

Fig. 3. The effects of repeated stimulation and lithium chloride treatment on IGF-1 gene expression. PC12 cells were incubated under control $\left(37^{\circ} \mathrm{C}\right)$ or hypothermic $\left(32^{\circ} \mathrm{C}\right)$ conditions with lithium chloride. IGF-1, insulin-like growth factor 1; CIRBP, cold-induced RNAbinding protein. The experiments were performed thrice, and the results represent the means. In the text, Fig. 3A and 3B are referenced. 
treatment resulted in a 2-fold reduction in IGF-1 gene expression levels compared with the control (Fig. 2B). Currently, the mechanism of this phenomenon is unknown. The timing of hypothermia treatment appears critical for the regulation of IGF-1 gene expression, and long-term exposure ( $>1$ day) to hypothermia treatment induced no change in IGF-1 gene expression. Next, we evaluated the effect on IGF-1 gene expression of repeated treatment cycles consisting of $2 \mathrm{~h}$ of normal temperature alternating with $2 \mathrm{~h}$ of hypothermia. The results showed that IGF-1 gene expression increased approximately 3-4-fold after $2 \mathrm{~h}$ of repeated switching between normal temperature and hypothermia (Fig. 3A). The results suggest that iterative hypothermia can be applied clinically. Next, we examined the effects of lithium chloride ( $\mathrm{LiCl}$ ), a well-known GSK-3 $\beta$ inhibitor (Lee and Han, 2010), on IGF-1 gene expression during hypothermic treatment (Fig. 3B). It was already reported that $\mathrm{LiCl}$ prevents hypothermia via Tau hyperphosphorylation and enhances $\beta$-catenin protein expression (Bretteville et al., 2012; Meffre et al., 2015). Two days of $\mathrm{LiCl}$ treatment at $37^{\circ} \mathrm{C}$ or $32^{\circ} \mathrm{C}$ resulted in up-regulation of IGF-1 gene expression, suggesting a role for unidentified intracellular thermal factors that interact with $\mathrm{LiCl}$ during hypothermia.

After an ischemic brain stroke, patient body temperature increases by $25 \%$ within $6 \mathrm{~h}$ and by $75 \%$ after $72 \mathrm{~h}$. The increase in body temperature is a phenomenon of the disease that serves as an indicator of stroke outcome. The in vitro findings of our study suggest that hypothermia could be used to control IGF-1 gene expression under clinical conditions. Further in vivo studies are required to verify these results and provide a possible means for developing treatments for brain ischemia recovery and diagnostic methods.

\section{Acknowledgements}

This study was supported by the research fund of Chungnam National University.

\section{Conflict of interest}

The authors declare no conflict of interest.

\section{REFERENCES}

Al-Astal HI, Massad M, AlMatar M, Ekal H. Cellular functions of RNA-binding motif protein 3 (RBM3): Clues in hypothermia, cancer biology and apoptosis. Protein \& Peptide Letters. 2016. 23: 828-835.

American Heart Association. 2005 American Heart Association (AHA) guidelines for cardiopulmonary resuscitation (CPR) and emergency cardiovascular care (ECC) of pediatric and neonatal patients: pediatric basic life support. Pediatrics. 2006 117: e989-1004.

Bretteville A, Marcouiller F, Julien C, El Khoury NB, Petry FR, Poitras I, Mouginot D, Lévesque G, Hébert SS, Planel E. Hypothermia-induced hyperphosphorylation: a new model to study tau kinase inhibitors. Scientific Reports 2012: 480.

Cheng G, Kim MJ, Jia G, Agrawal DK. Involvement of chloride channels in IGF-I-induced proliferation of porcine arterial smooth muscle cells. Cardiovascular Research. 2007. 73: 198 -207 .

Daughaday WH, Hall K, Raben MS, Salmon WD Jr, van den Brande JL, van Wyk JJ. Somatomedin: a proposed designation for the sulfation factor. Nature. 1972. 235: 107.

Imataka G, Arisaka O. Brain hypothermia therapy for childhood acute encephalopathy based on clinical evidence. Experimental and Therapeutic Medicine. 2015. 10: 1624-1626.

Lee YJ, Han HJ. Troglitazone ameliorates high glucose-induced EMT and dysfunction of SGLTs through PI3K/Akt, GSK-3 $\beta$, Snaill, and $\beta$-catenin in renal proximal tubule cells. American Journal of Physiology-Renal Physiology. 2010. 298: F1263 -1275 .

Meffre D, Massaad C, Grenier J. Lithium chloride stimulates PLP and MBP expression in oligodendrocytes via $\mathrm{Wnt} / \beta$-catenin and Akt/CREB pathways. Neuroscience. 2015. 284: 962-971.

Mullis PE, Patel MS, Brickell PM, Hindmarsh PC, Brook CG. Growth characteristics and response to growth hormone therapy in patients with hypochondroplasia: genetic linkage of the insulin-like growth factor I gene at chromosome 12q23 to the disease in a subgroup of these patients. Clinical Endocrinology. 1991. 34: 265-274.

Rinderknecht E, Humbel RE. Polypeptides with nonsuppressible insulin-like and cell-growth promoting activities in human serum: isolation, chemical characterization, and some biological properties of forms I and II. Proceedings of the National 
Academy of Sciences. 1976. 73: 2365-2369.

Rinderknecht E, Humbel RE. The amino acid sequence of human insulin-like growth factor I and its structural homology with proinsulin. The Journal of Biological Chemistry. 1978. 253: 2769-2776.

Rotwein P. Structure, evolution, expression and regulation of insulinlike growth factors I and II. Growth Factors. 1991. 5: 3-18.

Salmon WD Jr, Daughaday W. A hormonally controlled serum factor which stimulates sulfate incorporation by cartilage in vitro. Journal of Laboratory and Clinical Medicine. 1957. 49: 825-836.

Sturtevant J. Applications of differential-display reverse transcriptionPCR to molecular pathogenesis and medical mycology. Clinical
Microbiology Reviews. 2000. 13: 408-427.

Wardlaw JM, Murray V, Berge E, del Zoppo G, Sandercock P, Lindley RL, Cohen G. Recombinant tissue plasminogen activator for acute ischaemic stroke: an updated systematic review and meta-analysis. Lancet. 2012. 379: 2364-2372.

Yenari MA, Han HS. Neuroprotective mechanisms of hypothermia in brain ischaemia. Nature Reviews Neuroscience. 2012. 13: 267-278.

Yenari MA, Zhao H, Giffard RG, Sobel RA, Sapolsky RM, Steinberg GK. Gene therapy and vhypothermia for stroke treat- ment. Annals of the New York Academy of Sciences. 2003. 993: 54-68. 